\title{
The effects of beach width variability on coastal dune development at decadal scales
}

\author{
Filipe Galiforni Silva ${ }^{a}{ }^{*}$, Kathelijne M. Wijnberg ${ }^{a}$, Alma V. de Groot ${ }^{b}$, Suzanne J.M.H. Hulscher ${ }^{a}$ \\ ${ }^{a}$ Water Engineering E Management, Faculty of Engineering Technology, University of Twente, P.O. Box 217, 7500 AE Enschede, the Netherlands \\ ${ }^{\mathrm{b}}$ Wageningen Marine Research, Wageningen University and Research, P.O. Box 57, 1780 AB Den Helder, the Netherlands
}

\section{A R T I C L E I N F O}

\section{Article history:}

Received 26 April 2018

Received in revised form 12 December 2018

Accepted 16 December 2018

Available online 28 December 2018

\section{Keywords:}

Cellular automata models

Coastal dunes

Sediment supply

Beach Width

\begin{abstract}
A B S T R A C T
A cellular automata model is used to evaluate, over decadal time spans, the effect of beach width changes on the development of coastal dune systems. The model includes the effects of aeolian transport, hydrodynamic erosion and accretion, groundwater and vegetation growth. Simulations using fixed and mobile beach widths scenarios were carried out for a 90-year period. Unlimited and limited sediment supply conditions were regulated by groundwater depth. The final topographies were compared based on morphological characteristics such as dunefoot position and volume increase. Results show that there is a preferential cross-shore position where the foredune tends to be built which is a function of beach width and sediment supply. For narrow beaches, foredunes tend to develop at higher elevations than for wide beaches due to differences in wave dissipation, whereas dune volume is controlled by hydrodynamic erosion and dune recovery potential by sediment supply. Furthermore, if sediment supply is limited, the effect of beach width on dune volume only appears for beach widths greater than $300 \mathrm{~m}$, suggesting that limitation in supply can dominate dune growth on regular beaches whereas on wide systems, such as sand flats and spits, beach width size dominates. These results suggest that for a decadal scale, beach width controls the space available for dune formation, thus the position of the most seaward dune, but the effect of beach width on dune volume can be overruled by other supply limiting conditions such as groundwater depth.
\end{abstract}

(c) 2019 Elsevier B.V. All rights reserved.

\section{Introduction}

Coastal dunes are geomorphological landforms essential for flood defence against extreme surge levels. Their dynamics are conditioned by a bio-geophysical balance between aeolian transport, hydrodynamic processes (e.g. waves, tides, storms surges), beach morphology and geology, sediment availability and vegetation type and density (Hesp, 1983; Sherman and Bauer, 1993; Bauer and DavidsonArnott, 2002; Hesp, 2002; Delgado-Fernandez and Davidson-Arnott, 2011; Hesp and Walker, 2013). When wind blows across the beach surface above a velocity threshold, it initiates aeolian sediment transport. Over time, this sediment is deposited or/and captured by vegetation at the upper beach, leading to a bio-geophysical balance that controls dune initiation, growth and stabilisation (Hesp, 1983; Bauer et al., 2009; Bochev-van der Burgh et al., 2009; van der Burgh et al., 2011; Keijsers et al., 2015; van Puijenbroek et al., 2017). The amount of available sediment that can be transported towards the

\footnotetext{
* Corresponding author.

E-mail address: f.galifornisilva@utwente.nl (F. Galiforni Silva).
}

dunes is intrinsically related to grain size, surface moisture, shell pavement (i.e. surface lag), sediment armouring and beach morphology. Sediment supply and transport capacity are capable of controlling the type of dune-field that can emerge (Eastwood et al., 2011).

Several studies have shown that beach width and beach morphology can control sediment supply (Davidson-Arnott and Law, 1996; Bauer and Davidson-Arnott, 2002; Hesp, 2002), variability in sediment deposition on coastal dunes (Davidson-Arnott and Law, 1996; Burroughs and Tebbens, 2008; Keijsers et al., 2014), aeolian transport potential (Bauer and Davidson-Arnott, 2002; DelgadoFernandez, 2010) and potential for dune erosion due to extreme events (Davidson-Arnott et al., 2005).

Beach width often exhibits multi-annual to decadal scale variation (Clarke and Eliot, 1983; Stive et al., 2002; Quartel et al., 2008). Natural processes near tidal inlets, such as shoal attachment, bar welding, channel migration, as well as anthropogenic influence (i.e. nourishments), can directly affect beach morphology and, consequently, beach width (Wijnberg, 2002; Aagaard et al., 2004; Anthony, 2013; Heathfield and Walker, 2015; Cohn et al., 2017). However, few studies have addressed the effect of a time-varying beach width on 
dune evolution. Shoal attachments, shoreline sand waves and shore nourishments may drive changes in dune development over time. For example, a potential twofold effect of shoreline sand waves on dune dynamics is, for a wider beach width, an increased protection against storm wave attack and increased sand supply and, for the narrow beach width, a reduction of sand supply and less protected dunes (Stewart and Davidson-Arnott, 1988; Davidson-Arnott and Heyningen, 2003). Moreover, the local effect of rapid change in beach width over an annual to decadal scale has also been rarely studied.

An important reason for this is the lack of long-term data in relevant variables such as beach morphology, vegetation cover, meteorological and hydrodynamic conditions with high spatio-temporal resolution. For this reason, the use of numerical models that can work over such scales has been increasing in the past years, ranging from deterministic approaches (Barchyn and Hugenholtz, 2012; Durán Vinent and Moore, 2014) to rule based, probabilistic-based approaches (Nield and Baas, 2008; Eastwood et al., 2011; Keijsers et al., 2016) and coupled approaches (Zhang et al., 2015). In geomorphology, cellular automata models have been considered as a primary choice of reduced complexity modelling, with its strengths relying on its flexibility, relative low-computer effort requirements and range of modelling possibilities (Fonstad, 2006, 2013). Thus, the use of cellular automata models can be seen as a potential tool to analyse bio-physical interactions and responses due to small changes in an idealised, qualitative way. The objective of the present study is to evaluate the effect of changes on beach width for dune development in a decadal scale using a cellular automata model.

Section 2 describes the cellular automata model, highlighting its modules and assumptions. Section 3 describes all chosen test scenarios used as initial conditions for the model. Section 4 describes the results divided by two main groups defined by the initial conditions. Section 5 presents a discussion of the results and the comparison between model results and real patterns.

\section{The DUBEVEG model}

The DUBEVEG model (Keijsers et al., 2016) is a cellular automata model built to simulate dune development at the coastal land-water interface. It includes an aeolian sediment transport component, hydrodynamic sediment input and erosion, groundwater and biotic processes related to vegetation. Sand transport, vegetation growth, and dune development are simulated by probabilistic rules that mimic crucial bio-physical feedback interactions for dune growth, dune development and decay (Fig. 1). It is meant to analyse trends, patterns and feedback concepts important for dune evolution in a coastal scheme. The model structure is divided in three modules which interact throughout the simulation and subsequently reorganise the "sand slabs" (square-shaped model representation of a standard volume of sand) that are displaced over the domain: an aeolian transport module, a hydrodynamic module and a vegetation module.

The transport module is the core of the model and represents aeolian sediment transport by assigning probabilities of erosion and deposition to each sand slab at the surface. The probabilities can change according to several factors such as presence of vegetation and the state of surrounding cells. Based on these probabilities, certain cells move downwind and self-organise themselves in bedforms and dunes. By the movement of the slabs downwind, the model mimics the amount of sand that moves a certain distance over a period of time. Thus, the model does not explicitly use wind strength or related shear stress but rather simulates the sediment transport itself assuming that for each time step, there is a certain probability that the slab will or not be transported (in reality, wind threshold to initiate transport is achieved or not). Thus, sediment transport can vary in time and space randomly. Vertically, the number of cells available for transport is defined by a specified mean sea level and the groundwater level. The groundwater level is defined as a proportion of a pre-defined reference surface and represents the depth at which water saturation (e.g. moisture content) is high enough to shut down aeolian transport. The reference surface conceptually represents an equilibrium "profile" for the storm surge impact simulated by the hydrodynamic module.

The hydrodynamic module represents a re-arrangement of the beach topography due to hydrodynamic forcing and is simulated using a rule-based approach that gives a probability $P_{\text {hydro }}$ to each cell to return to its reference height, as defined by the reference surface.

$P_{\text {hydro }}=\left(1-R_{v}\right) \times\left(\left(W_{E}-W_{\text {diss }}\right)+P_{\text {inun }}\right) \times S$

where $R_{v}$ is the resistance of erosion due to the vegetation, $W_{E}$ is the maximum erosive strength of the waves, $W_{\text {diss }}$ is a cumulative dissipation factor based on an inverse function of the remaining water depth in the cross-shore direction, $P_{\text {inun }}$ is the probability of bed level update due to the inundation regardless of the presence of waves, and $S$ is the stochasticity term representing unaccounted or unpredictable conditions (e.g. grain size variability, wave/current interactions). The total water level is defined as a sum of an imposed water level (i.e. tide gauge measurements) plus a wave run-up estimate based on an empirical parametrisation described in Stockdon et al. (2006). Inundated cells receive a certain probability $P_{\text {hydro }}$ based on Eq. (1) which is used to define whether the cell will be reset to its reference profile height or not, being 1 a full chance of reset and 0 a null chance. As a result, this can lead to either erosion or accretion of the cells depending on the elevation of the cell relative to the reference profile. Therefore, the hydrodynamic module controls the sediment balance of the model. It ensures sufficient feeding and erosion from the sea to maintain a certain long-term equilibrium scheme for the overall beach elevation on which dunes may develop.

The vegetation module mimics the growth and decay of dune vegetation using growth curves as a function of bed level change. The vegetation is incorporated by a dimensionless value called Vegetation Effectiveness, which mimics how vegetation affect the potential for aeolian sand transport and deposition (Nield and Baas, 2008). Also, vegetation plays a role in the hydrodynamic module, as represented in Eq. (1). New vegetation can appear either by lateral expansion or by random establishment over bare cells. The probability of establishment, which represents germination from seeds and rhizomes, is assumed to be constant for all bare cells. According to Nield and Baas (2008), comparison between model results and real cases are acceptable due to the physiological characteristics introduced by the vegetation, which adds a direct scale in time and space to the model. Regarding vegetation cover, the model accounts for two species: incipient and conservative. The parameters used for all scenarios are presented in Table 1.

A common validation practice among cellular automata modellers is the comparison of patterns that emerge within the model with patterns on real sites. Deterministic validation approaches in cellular automata modelling have been done recently and yield also some level of confidence in cellular model results (Zhang et al., 2015; Keijsers et al., 2016). Although an important advance, such approaches do not necessarily mean that, for the long-term, uncertainties are small enough to make model results reliable. In a nonlinear system, different combinations can lead to similar results, and final results can differ due to small variations on initial conditions. In the present study, we make use of the validation done by Keijsers et al. (2016), together with some real world data comparison. Validation and further details on the model can be found in Keijsers et al. (2016). 


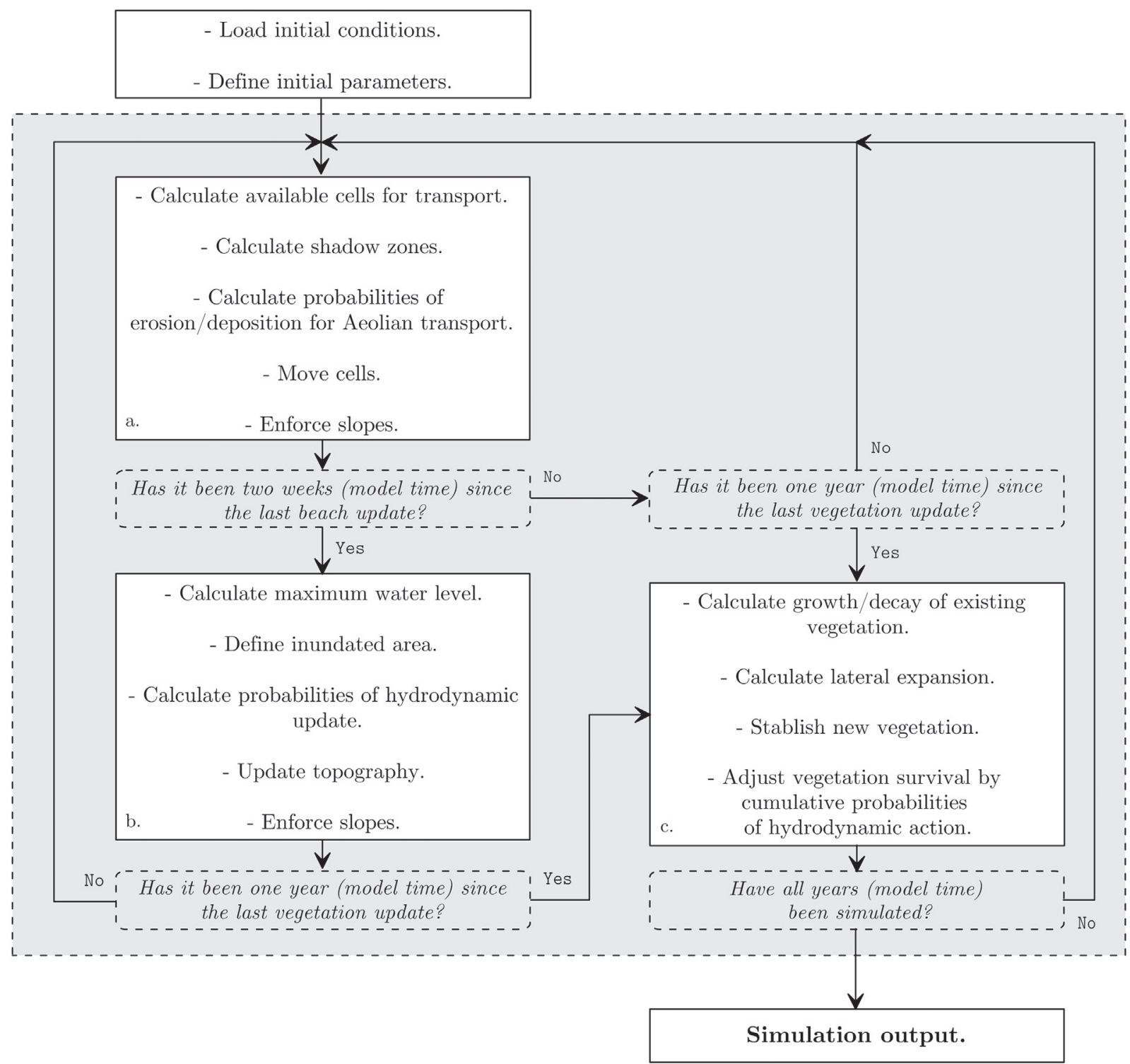

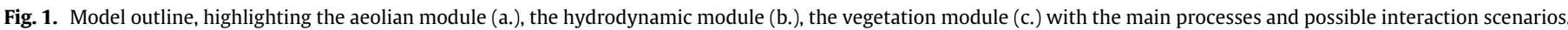
Source: Adapted from Silva et al. (2018).

\section{Test scenarios}

In order to evaluate the effects of varying beach width on dune development, static and dynamic scenarios have been tested. Static scenarios are defined as a case with a non-varying shoreline position in time, whereas dynamic scenarios are defined by forced changes

Table 1

Summary of standard values used on the simulations. Values used are based on Keijsers et al. (2016).

\begin{tabular}{lll}
\hline Parameter & Value & Unit \\
\hline Cell length and width & 1 & Meters \\
Cell height & 0.1 & Meters \\
Probability of deposition on a sandy cell $\left(P_{d}\right)$ & 0.1 & - \\
Probability of erosion of a sandy cell $\left(P_{e}\right)$ & 0.5 & - \\
Shadow angle & 15 & Degrees \\
Resistance to erosion due to vegetation $\left(R_{v}\right)$ & 0.5 & - \\
Dune Sheltering & 0.8 & - \\
Wave dissipation strength $\left(W_{\text {diss }}\right)$ & 0.012 & - \\
Probability of reset due to inundation $\left(P_{\text {inun }}\right)$ & 0 & - \\
Maximum erosive strength $\left(W_{E}\right)$ & 1 & - \\
\hline
\end{tabular}

in beach width by shoreline migration throughout the simulations. Simulations were carried out for a model run of 90 years to account for several decadal periods. For all simulations, the hydrodynamic and vegetation modules are called after two-weeks and one-year model time, respectively. For all simulations, initial values of vegetation effectiveness are assigned randomly with values between 0 and 0.5 at slabs higher than $2 \mathrm{~m}$ above MSL and 0 at slabs below $2 \mathrm{~m}$ above MSL.

To evaluate the amount of variability in results arising from internal stochasticity and the number of necessary replicates, three different cases have been chosen (Table 2). Whiskers would indicate the range of possible outcomes for the same initial conditions. In the present study, whisker extremes are used to evaluate the range of possible outcomes for the same initial conditions. Furthermore, it can be used to conclude whether outcomes are consistently different or not among different simulation conditions. Furthermore, to determine the amount of replicates necessary, we used the Confidence Interval method (Hoad et al., 2011; Law, 2014). The method aims at finding the number of replicates necessary to narrow the confidence interval up to a specified precision $d_{m i n}$. Precision $d$ is defined as half 
Table 2

Summary of number of replicates used to evaluate internal stochasticity of the model

\begin{tabular}{|c|c|c|c|c|}
\hline Test case & Initial beach width (m) & Final beach width (m) & Return period (years) & Number of replicates \\
\hline Static & 150 & 150 & n.a. & 36 \\
\hline Static & 500 & 500 & n.a. & 36 \\
\hline Static & From 50 up to 1000 & Same as initial & n.a. & 20 \\
\hline Dynamic (Case A) & 1000 & 500 & 15,45 and 90 & 20 \\
\hline Dynamic (Case B) & 500 & 150 & 15,45 and 90 & 20 \\
\hline Dynamic (Case C) & 300 & 200 & 15 (subsequently) & 36 \\
\hline
\end{tabular}

width of the Confidence Interval in terms of percentage of the sample mean:

$d_{n}=\frac{100 \times t_{n-1, \alpha / 2} \times s_{n} / \sqrt{n}}{\bar{X}_{n}}$

where $n$ is the number of replications, $t$ is the student $t$ value, $\bar{X}_{n}$ is the mean and $s_{n}$ is the standard deviation. For the present research, a stopping criteria is chosen when: values of $d$ are smaller than $5 \%$ or after a sudden drop of rate of change with the increase of replicates (thus increasing number of replicates does not lead to a decrease in precision values).

For the static scenarios, simulations over 20 idealised beach widths were carried out, with values ranging from a beach width of $50 \mathrm{~m}$ (e.g. regular beaches) up to $1000 \mathrm{~m}$ (e.g. sand flats near inlets, spits). The initial topography was built based on an available beach topographic measurement of the Dutch coast. This surface was processed to remove the foredune and smoothened using a Gaussian low-pass filter. Then, two nodal points were defined (1.5-m and $0-\mathrm{m}$ contour), and the cross-shore position of each node was changed to represent the aforementioned beach widths. The initial profile was also used as the model reference surface.

Water level time series from a tide-gauge in the North Sea (Texel Inlet) were used, so the same water level time series is used in all simulations. Two groundwater level settings are used to simulate distinct sediment supply cases: a limited supply case (i.e. high groundwater levels) and an unlimited supply case (i.e. deep groundwater levels).

From the output, the domain was divided in 100 cross-shore profiles alongshore and for each profile, dune volume, foredune distance to the $0-\mathrm{m}$ contour and the initial profile height at the position of the new foredune were calculated. Dune volume was calculated by integrating all cells above 3-m contour. Foredune distance to the $0-\mathrm{m}$ contour is calculated by the cross-shore distance between the dunefoot (i.e. 3-m contour) and the $0-\mathrm{m}$ contour. Initial profile height at foredune position is the height of the initial profile at the final dunefoot location (i.e. at the end of the simulation). The parameter average of all cross-shore profiles is used to define final values for each scenario. Results are compared both over time and between different initial beach widths and slopes. Slopes are defined between 0 and $1.5-\mathrm{m}$ contour, displayed as the onshore directed gradient. The relation between beach slope and beach width is a negative exponential function, on which small beach width have higher values of beach slope.

For the dynamic scenarios, variations in beach width in time during the simulation are implemented by changing the reference profile (thus, shifting the shoreline) accordingly, in a similar approach used by Keijsers et al. (2016) for sea-level rise adaptation. Three different cases have been tested in this scheme: A- beach width of

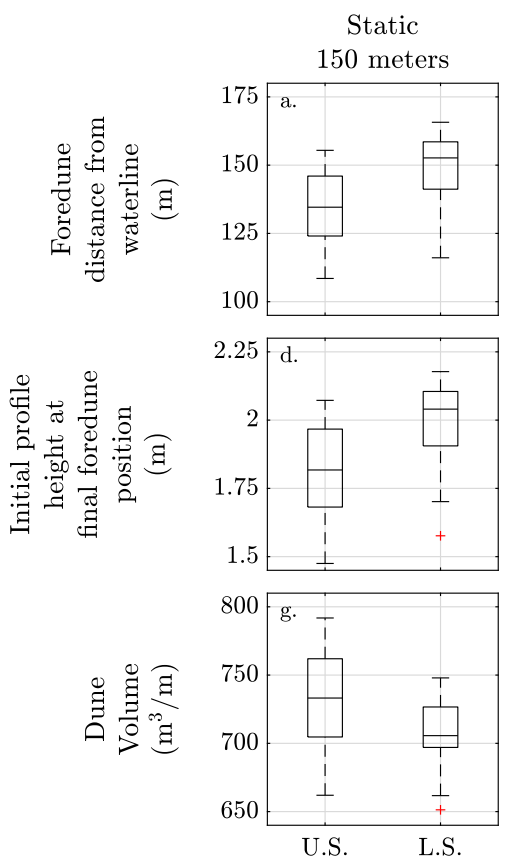

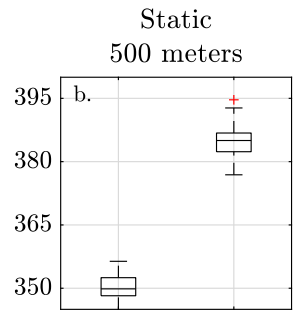
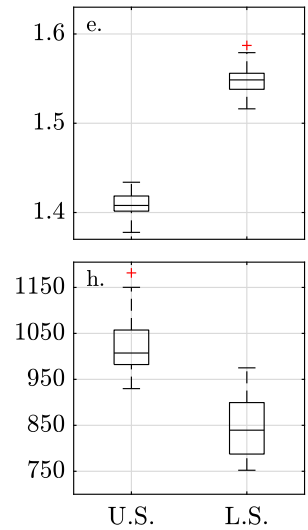
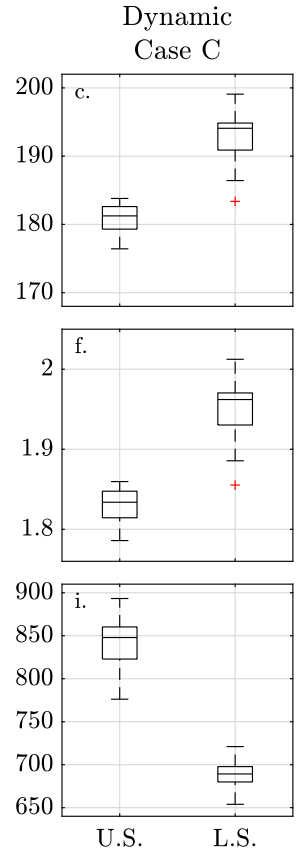

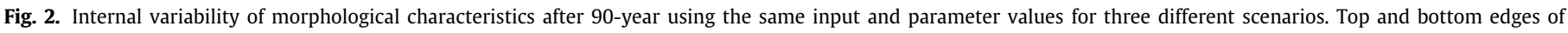

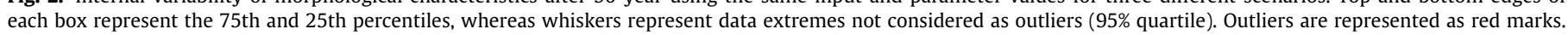
U.S. = Unlimited supply. L.S. = Limited supply. Note different scaling of y-axis between the three scenarios. 


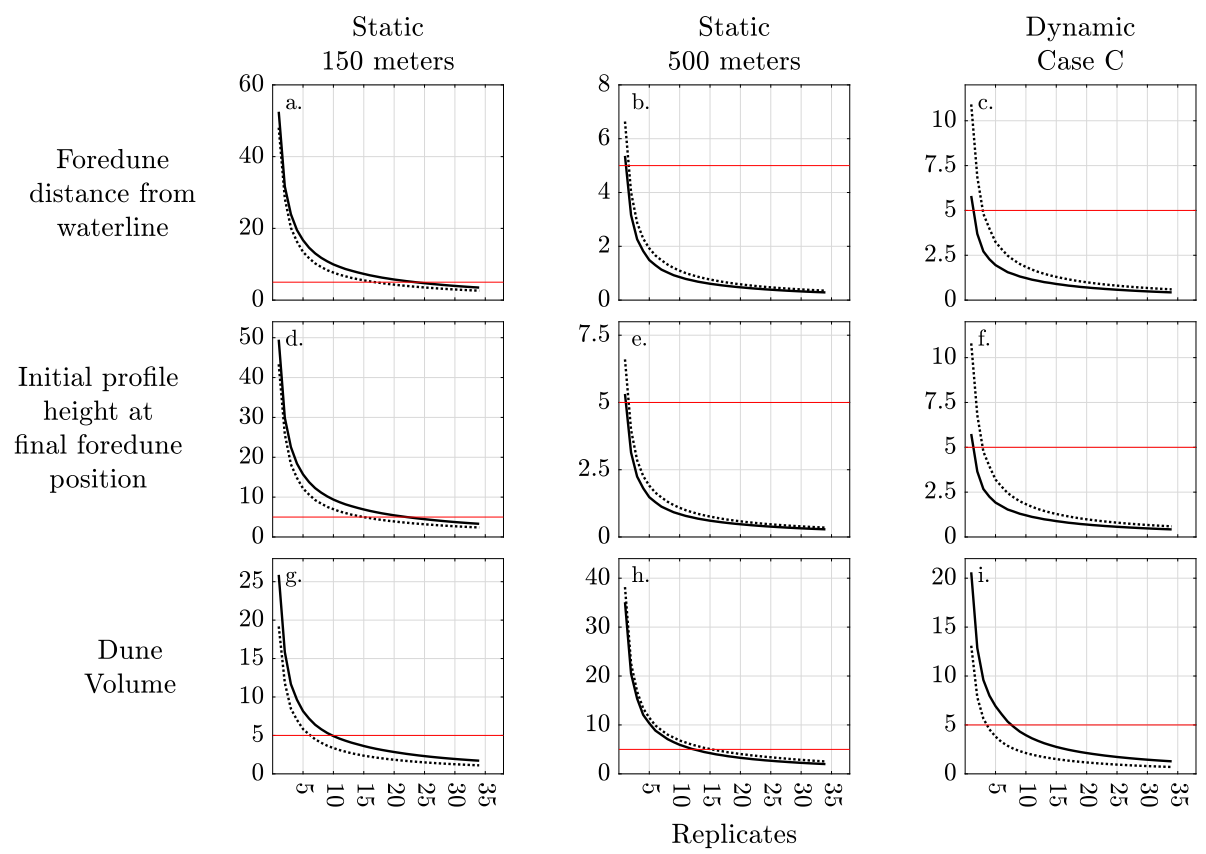

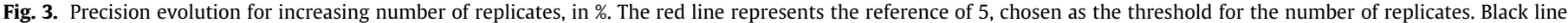

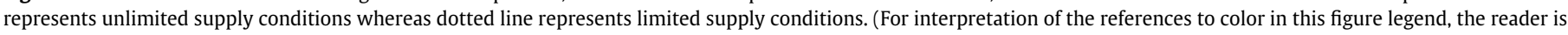
referred to the web version of this article.)

$1000 \mathrm{~m}$ eroding until $500 \mathrm{~m}$; B - beach width of $500 \mathrm{~m}$ eroding to a beach width of $150 \mathrm{~m}$, and $\mathrm{C}$ - periodic beach width change ranging from $300 \mathrm{~m}$ to $200 \mathrm{~m}$, based on shoal attachment events observed on the island of Terschelling (NL) (Ridderinkhof et al., 2016). Furthermore, a range of shoreline retreat rates have been tested for case $A$ and $\mathrm{B}$, in which the shoreline retreats to its final position in 15,45 and 90 years and remains stable at the final position for the remainder of the simulation. For $C$, the same cycle of shoreline advance and retreat is repeated every 15 years, in line with shoal attachment behaviour found by Ridderinkhof et al. (2016). From these results, final topographies are evaluated in the same way done in the static scenarios and compared in terms of morphology, volume growth and foredune position.

Model results are compared qualitatively to observed dune development on two sites at the Dutch coast: Egmond beach, as an example of narrow beach, and the island of Ameland, as an example of wide beaches. Egmond is a sandy beach located in the western coast of the Netherlands with a beach width in the order of $100 \mathrm{~m}$. Ameland is one of the barrier islands from the Wadden Sea, with length of about $24 \mathrm{~km}$ and a visible pattern of beach width change due to shoal attachments on its west side. Both sites have annual LiDAR data available from 1997 up to 2017 with spatial resolution of

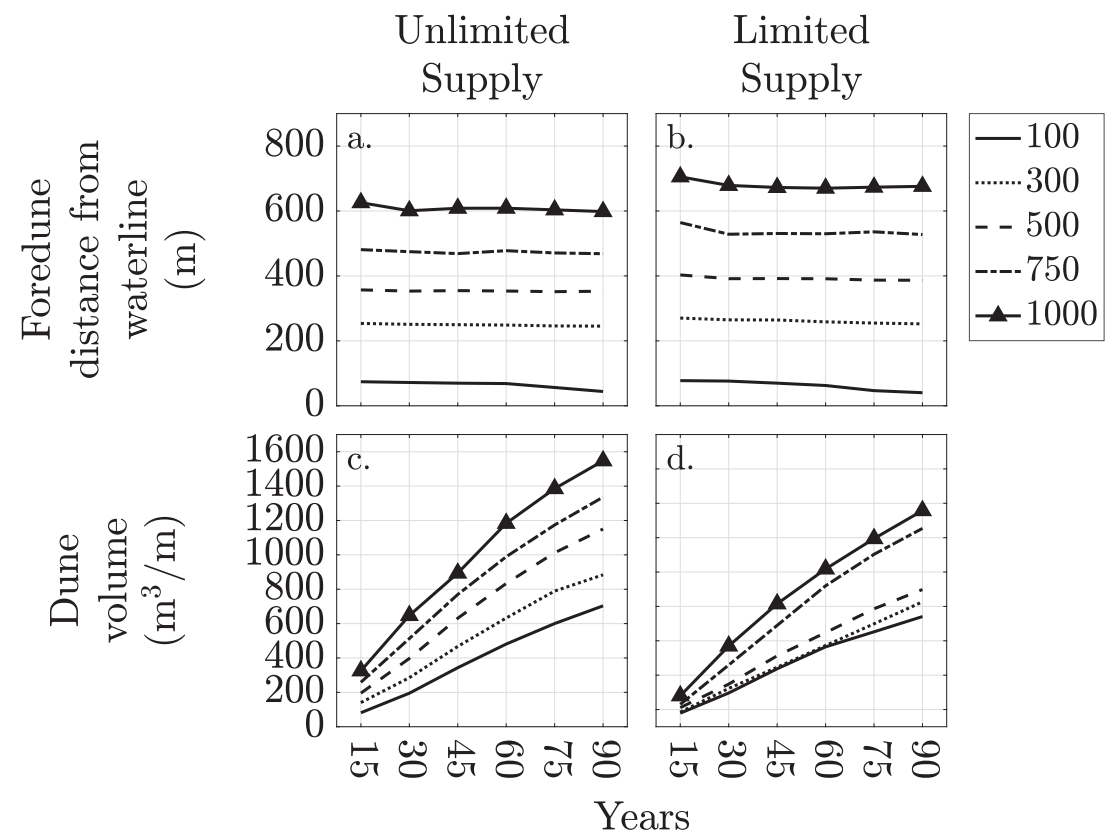

Fig. 4. Beach-dune morphological evolution for 5 distinct beach width for an unlimited supply scenario (left) and a limited supply scenario (right). 
$5 \mathrm{~m}$ (up to 2012) and $2 \mathrm{~m}$ (after 2012), which are analysed together with satellite images from Google Earth to avoid misinterpretations due to spatial and time resolution limitations found in the LiDAR data set (e.g. appearance and erosion between surveys, limiting grid size for incipient dunes).

\section{Results}

\subsection{Internal variability}

Three main differences can be pointed out from the internal variability test: simulations using a narrow beach $(150 \mathrm{~m})$ present higher internal variability than a wider beach $(500 \mathrm{~m})$; there is an overlap of quartile values when comparing unlimited and limited supply for narrow beaches; the dynamic case presents less internal variability than the narrow case, even though final beach widths are similar (Fig. 2).

Higher variability on narrow beaches means that the range of possible outcomes (i.e. dune characteristics) is wider than those for wide beach widths. As an example, the range of initial profile elevation at the final foredune position for an unlimited supply case for a narrow beach condition is approximately $0.5 \mathrm{~m}$, which is more than 10 times the range for a wide beach scenario. For dynamic cases, the effects of internal stochasticity are relatively small and results for the two supply conditions produces no overlap between boxplots whiskers.

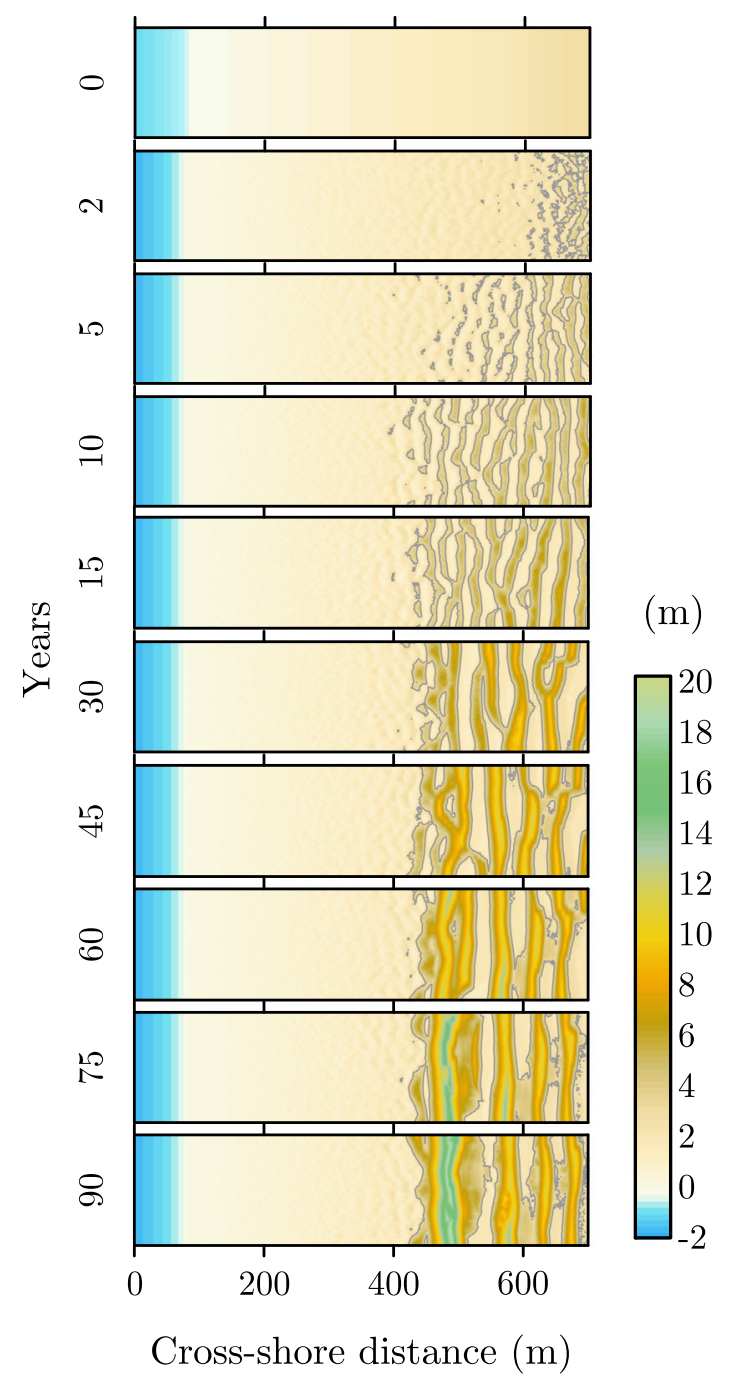

Fig. 5. Dune evolution over time for an unlimited supply scenario.
In general, narrow beaches can produce a higher range of outcomes for the same initial conditions than wider beaches.

Regarding replicates, results show that all criteria are met when at least 20 replicates are done (Fig. 3). Also, the number of replicates necessary is sensitive to the parameter chosen, with some parameters leading to the achievement of the $5 \%$ precision criteria within 5 replicates.

\subsection{Static scenarios}

\subsubsection{Unlimited supply scenario}

Over time, results show a trend of dunes evolving in a preferential position along the beach profile. The location varies according to the initial beach width conditions and maintain its position since early stages. For most cases, this position is reached within 15-30years (Fig. 4a). Dunes start as small bedforms in the area landward to the aforementioned position, evolving into dunes as vegetation starts to grow. The following years are defined by a rearrangement of dunes behind the recently built foredune into a sequence of long dune rows (Fig. 5). The presence of a stable position can be seen in all cases, regardless of its initial beach width. Dune volume increases steadily throughout the entire simulation (Fig. 4c). Although different in magnitude, all beach width scenarios had an increase of at least 4 times the volume after 15 years by the end of the simulation.

Comparing different initial beach widths, the final foredune distance to the waterline tends to increase with the initial beach width (Fig. 6a). When compared to the slope, an inverse dependency appears, with higher values of slope leading to a reduction of final dune volume, although not in a linear scheme (Fig. 6b). Alternatively, the initial profile height at the final foredune position decreases with the increase of the initial beach widths. This means that the foredune on a wide beach tends to develop at lower elevations than on narrow beaches. Regarding dune volume, final values tend to increase
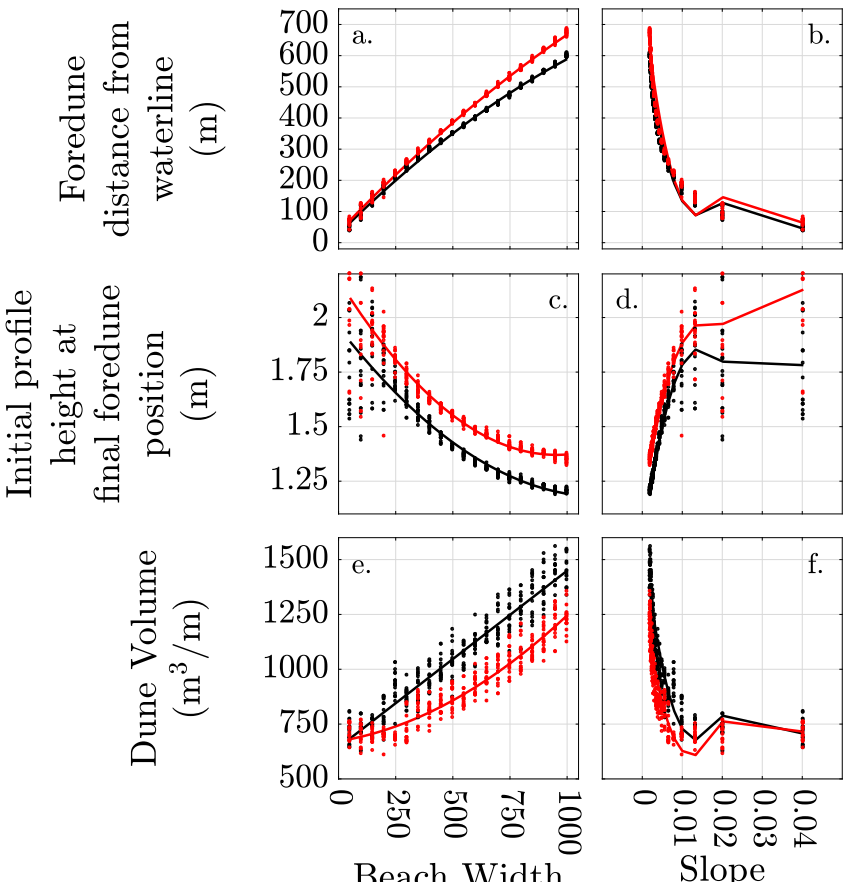

(m)

Fig. 6. Differences of beach-dune morphological characteristics after 90-year simulation. Black lines and dots represent unlimited supply scenarios, whereas red lines and dots represent limited supply scenarios. Dots represent average values whereas lines are approximate fitting curves. (For interpretation of the references to color in this figure legend, the reader is referred to the web version of this article.) 
$(\mathrm{m})$

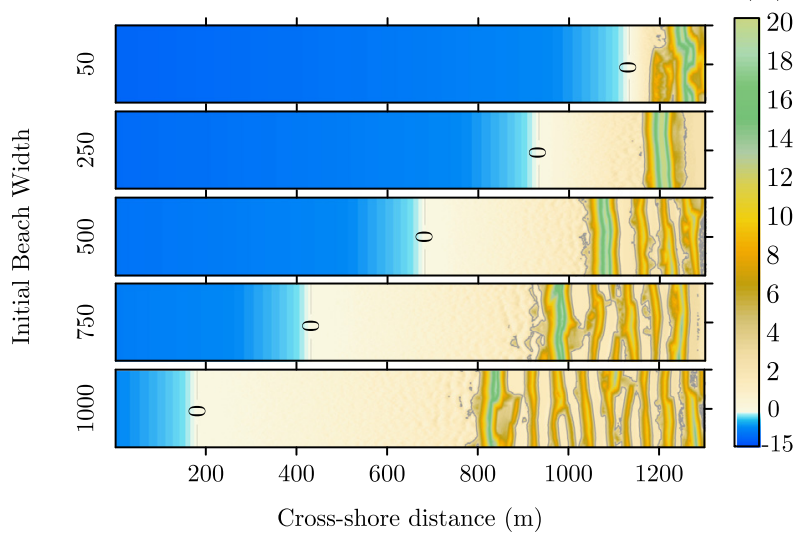

Fig. 7. Morphological differences on dune evolution after 90 -years for 5 different beach width.

linearly with the increase of beach width (Fig. 6e). Similar to the foredune position, dune volume tends to increase prominently for slopes smaller than 0.01 (Fig. 6f). In terms of morphology, results show an overall trend of long dune rows developing over the area landward of a limit position. For beach width of $100 \mathrm{~m}$, the foredune develops a crest height of up to $20 \mathrm{~m}$, which is higher than for wider beaches. For wider beach widths, due to the available space, a sequence of dune rows emerges. For most cases, the seaward most dune eventually tends to be higher than the ones behind it (Fig. 7).

\subsubsection{Limited supply scenario}

Patterns regarding foredune distance from the waterline and profile initial height at foredune position, for the limited sediment supply scenario, are similar to the unlimited scenario, with changes in magnitude only. Over time, the foredune reaches its stable position within 15-30 years, although for most beach width cases its location is farther from the sea than the unlimited supply condition (Fig. 4a, b). Dune volume also follows the same pattern as the unlimited supply scenario in time, although with smaller values, especially for wider beach widths (Fig. 6).

When comparing different beach widths, increasing the beach width resulted in longer foredune distances from the waterline compared to the unlimited supply scenario. The same dependency pattern appears when comparing the initial profile height at the foredune position, which tend to develop in higher positions than the unlimited scenario.

Interesting though, the dependency changes for dune volume, which presents a quadratic dependency for limited supply scenarios, in contrast to the linear-shaped behaviour in unlimited supply scenarios. In terms of morphology, the overall trend is similar to those found on unlimited supply scenarios, with embryonic dunes emerging up to a certain cross-shore position and with the most seaward one growing more substantially than the ones behind it. The main difference, due to the limitation in supply, is the spacing of the dunes, which is greater than if the supply is not limited.

\subsection{Dynamic scenarios}

For dynamic scenarios, final values of foredune position and dune volume after 90-year simulation are illustrated in Fig. 8. Overall, results show a spatiotemporal pattern that dunes tend to be built closer to the waterline for retreat periods of 45 and 90 years. In Case A, for unlimited supply conditions, the average dune volume and average foredune position are considered statistically significant different between all retreat scenarios (Table 3). Moreover, for a retreat period of 45 and 90 years, foredunes tend to develop closer to the final waterline position than for a retreat period of 15 and the static scenario, with values ranging between $350-300 \mathrm{~m}$. The same spatiotemporal pattern can be seen in Case B (Fig. 8), with values of foredune position being closer to the waterline for retreat period of 45 and 90 years in an unlimited supply condition. For a limited supply condition, this pattern is less prominent. Average dune volume and foredune position for retreat periods of 45 years are not significantly different from those for static and 90 -year retreat scenario. However, Case B presents a spatiotemporal pattern similar to the unlimited supply condition of longer retreat periods translating into foredunes positioned closer to the waterline. For Case C, limited supply scenarios did not yield statistically different average values between static and dynamic scenarios. For unlimited supply, results from static and dynamic scenarios are statistically different, with mean values of static scenario being slightly lower than the dynamic scenario. Furthermore, the range of possible outcomes are much higher for the static than the dynamic scenario.

Regarding dune volume, for Case A, static scenarios present higher values than all dynamic scenarios. For Case B, only retreat periods of 15 years resulted in a significant different mean than all the other scenarios for an unlimited supply condition. No statistical difference emerge when considering limited supply conditions

\section{Case A}

\section{Case B}

\section{Case C}

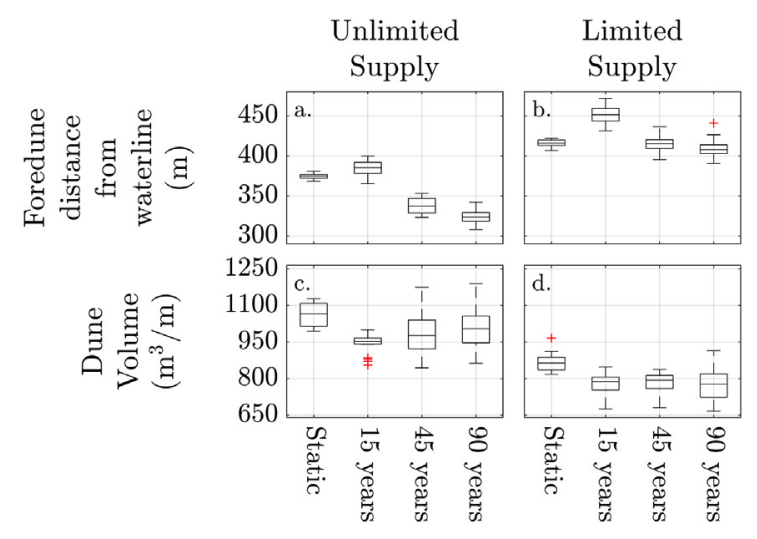

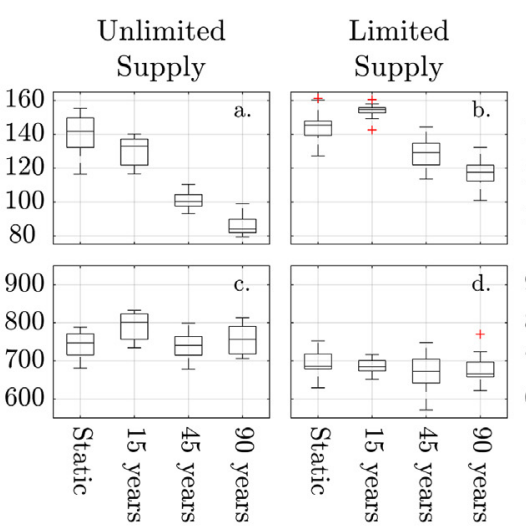

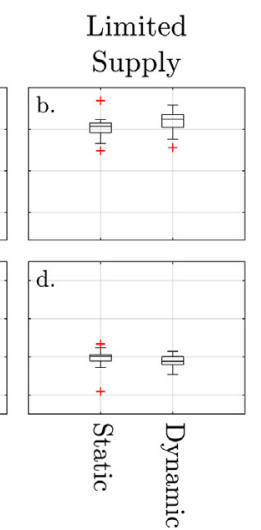

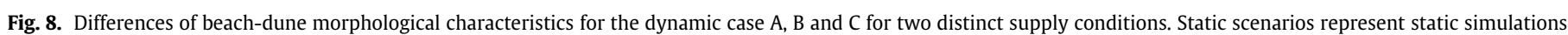
with beach width of 500,150 and $200 \mathrm{~m}$, respectively. 


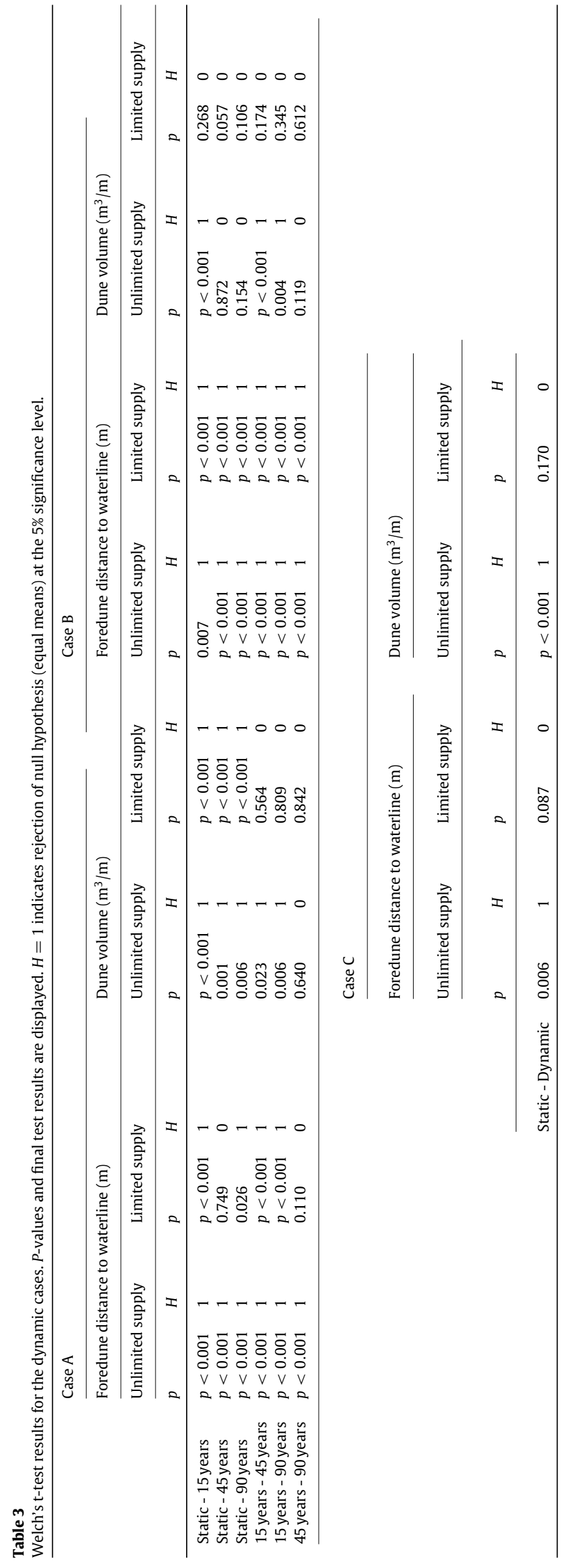

for Case B. For Case C, dynamic scenarios yield higher values than the static scenario for an unlimited supply condition, whereas no significant difference can be seen for a limited supply condition.

Morphologically, static and dynamic scenarios with 15-year retreat period yield higher foredunes than dynamic scenarios with a retreat period of 45 and 90 years. Furthermore, the same trend of dune rows landward to the foredune remains for the cases where space is available (Fig. 9).

\subsection{Real cases}

Regarding real cases, Egmond presents a local erosion trend of the foredune (Fig. 10a). The beach width ranged from $75 \mathrm{~m}$ up to $135 \mathrm{~m}$. Satellite images from 2005 and 2007 show a retreat of the dunefoot by about $5 \mathrm{~m}$, which in 2013 ends with a retreat of approximately $20 \mathrm{~m}$. In 2013, a linear group of incipient dunes start to emerge close to the foredune position of 2005 (Fig. 10b, 2013). This small linear incipient dune belt disappeared in 2015 and can be seen again in 2017 , on a position similar to that the foredune of 2005 , suggesting a preferential position of dune growth. Regarding profile height, comparing the position of the new belt of incipient dunes with the average height at the location using all available LiDAR data yield average values of $2.6( \pm 0.5) \mathrm{m}$.

For Ameland, shoreline evolution patterns due to shoal attachment build two interesting locations: one east of the attached shoal, with a sudden increase of beach width after 1997; and a second location on the west of the shoal where the beach width is wide for at least 15 years (Fig. 11a). For the east location, incipient dunes start to emerge in front of the foredune after 2005, which is in accordance with the time of beach width increase (Fig. 11b, red box). For the west part, incipient dunes also emerge in front of the foredune, although this time expanding much further than the eastern region (Fig. 11b, purple box). Also, regarding profile height, comparing the position of the new belt of incipient dunes with the average height yield lower values for the western part than the eastern part, with average values of $1.8( \pm 0.2) \mathrm{m}$ and $2.4( \pm 0.1) \mathrm{m}$ for the wider and narrower beach width, respectively. Differently than Egmond's case, the locations at the Ameland case present different shoreline orientation regarding the main wind direction quadrant (W-SW). That means that the east sector presents potential enough fetch in a higher percentage of the wind events than the west sector. Nevertheless, the development of incipient dunes after 2005 suggests that both sites present enough aeolian sediment transport for dune development.

\section{Discussion}

Three main characteristics can be pointed out when comparing results of simulations for different beach width conditions: 1 . there is a preferential cross-shore position where the foredune tends to grow, on which the vertical growth tend to overcome horizontal expansion; 2 . the foredune distance from waterline increases with the beach width, whereas the elevation on which the foredune develops decreases with beach width (lower for wider beaches); 3 . for limited supply conditions, a minimum beach width size seems to exist beyond which the width starts to effectively affect dune volume.

Results show a tendency for dunes to expand until a limit point in the cross-shore direction, as shown by static simulations, on which most horizontal expansion takes place in the first 30 years of simulations for most scenarios. The dune system will change from a horizontal expansion trend to a vertical growth trend of the foredune when it reaches a preferential position. Data from Egmond beach also suggest an existence of a preferential position, where a position seems to exist on which the foredune tend to be rebuilt after an erosion period. For Ameland, the response of expanding dunefield 
Unlimited supply

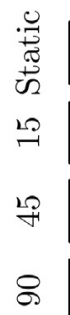

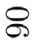

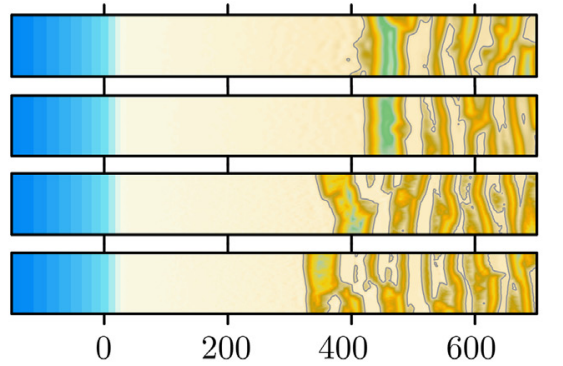

Limited supply
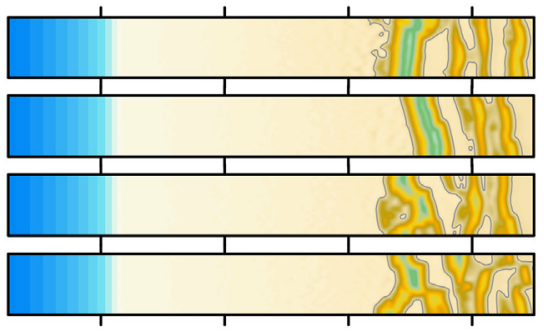

0

$200 \quad 400$

600

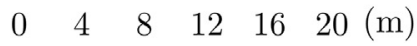

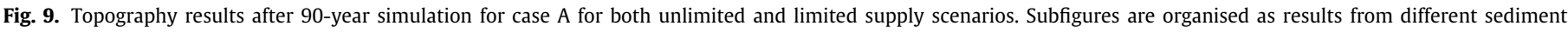

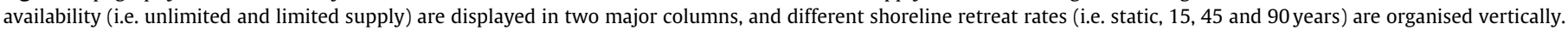
The $\mathrm{x}$-axis for each subfigure represents the cross-shore position $(\mathrm{m})$ whereas the $\mathrm{y}$-axis represents the alongshore position.

after widening of the beach also seems consistent with model results. Ruessink and Jeuken (2002) have shown that, for the Dutch coast, shoreward extensions of beach width lead to similar patterns on dunefoot, which is in accordance with our findings. Furthermore, Ruessink and Jeuken (2002) imply that time-space variability in beach characteristics control the residual dunefoot variability. An increase/decrease in beach width would lead, if enough time is given, to an expansion/retreat of the dunefoot. This explains also why dunes tend to develop closer to the waterline in the dynamic scenarios for longer retreat periods (45 and 90 years). For longer periods, dunes have time to reach its preferential cross-shore position and increase vertically, becoming established and resistant to retreat. Thus, the probability of dunes surviving closer to the waterline is higher as they also act as a buffer for the retreat period. Expansion and retreat of dunefoot due to changes in beach characteristics can also be seen in evolution models for coastal dune fields proposed by Hesp (2002, Fig. 3, accretion cycle) and Hesp and Walker (2013, Figs. 8a, b). The main difference would be the time
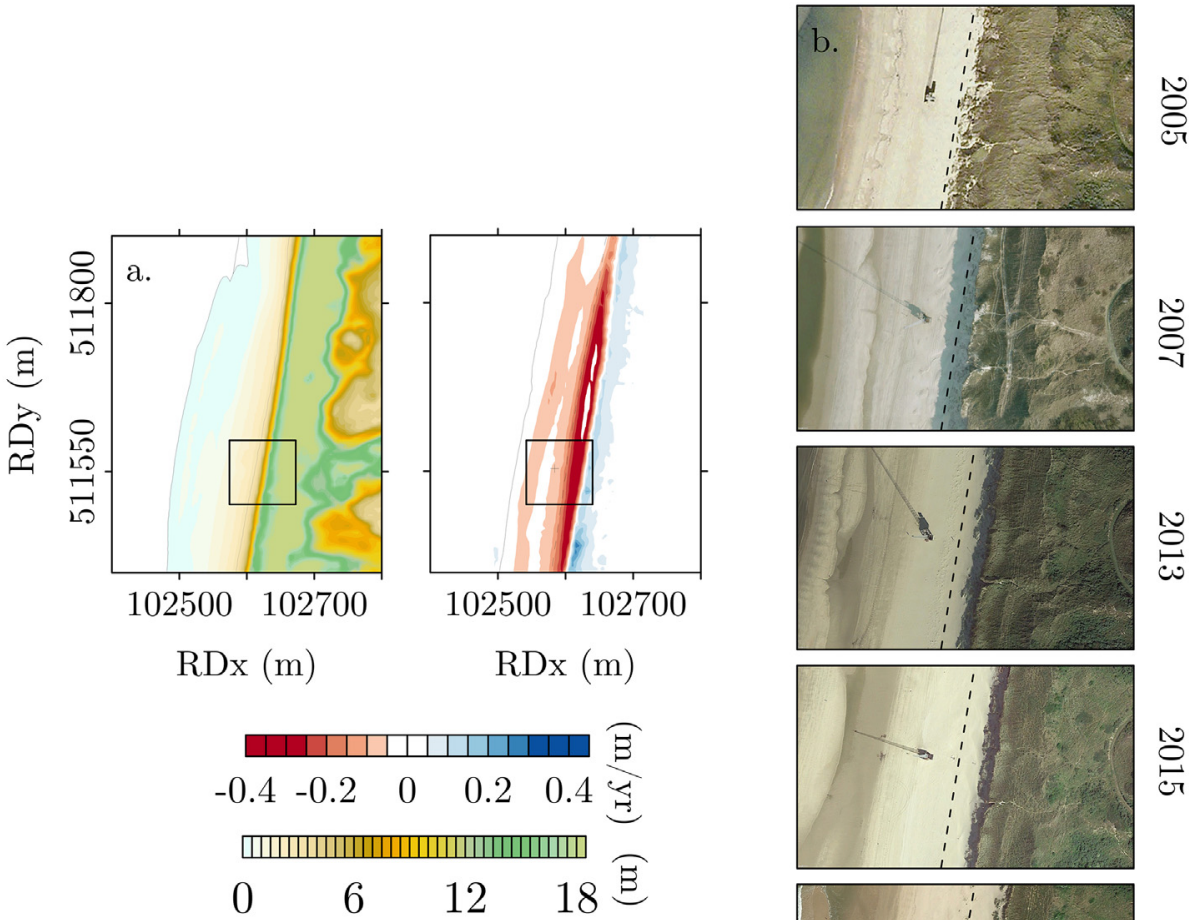

용
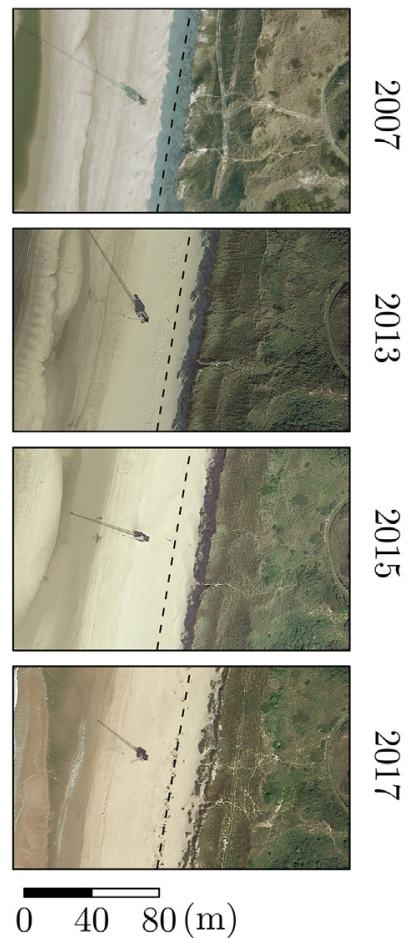

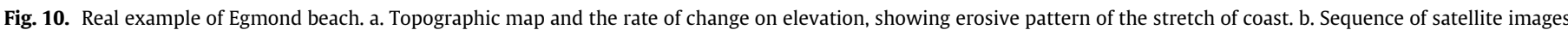

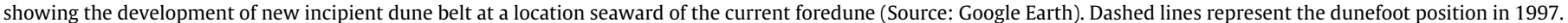


a.
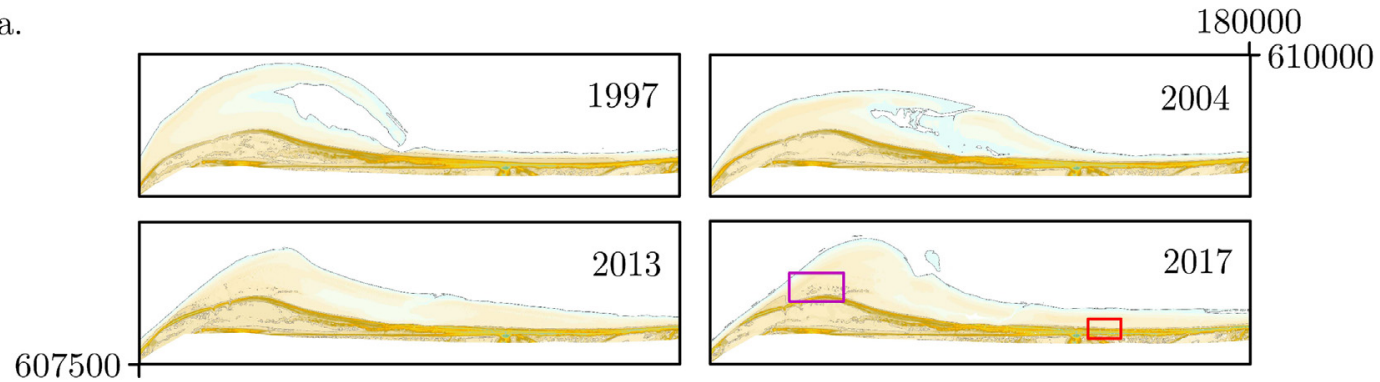

170500

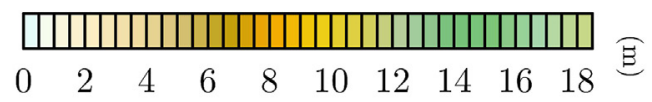

b.
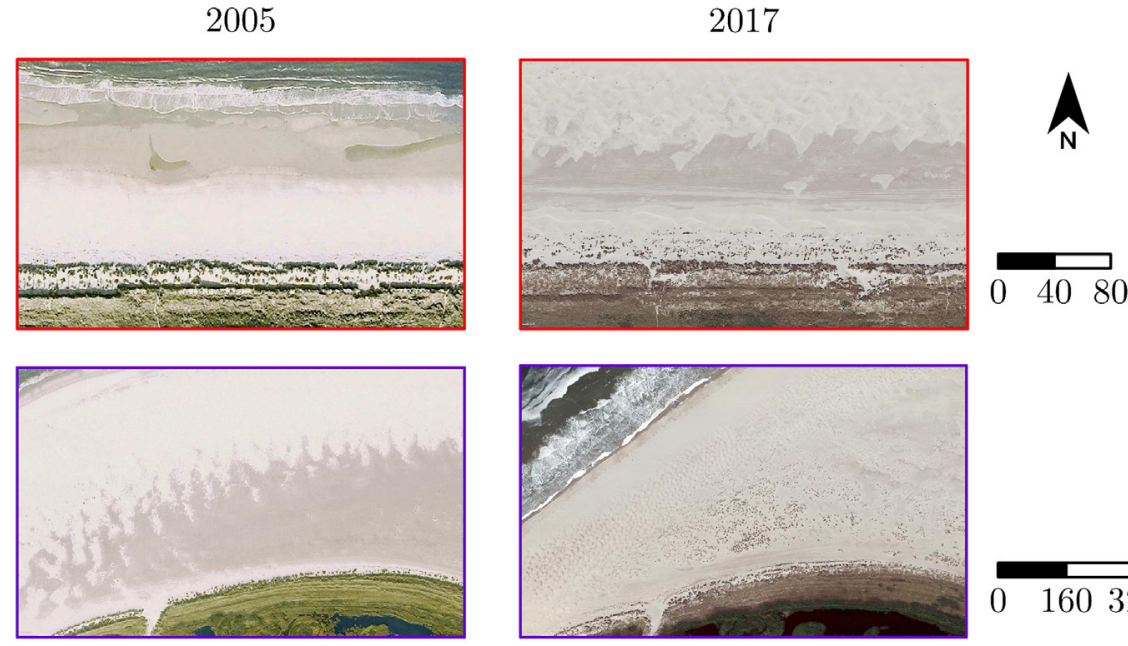

$0 \quad 160320$

c.

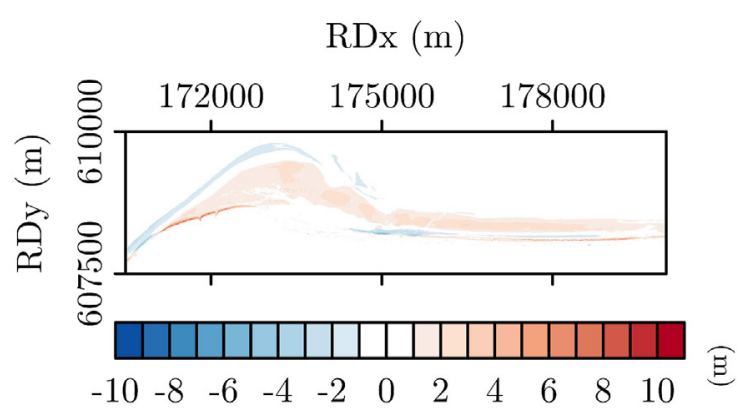

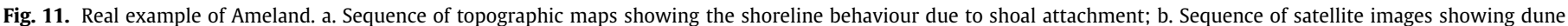

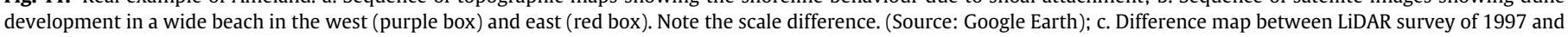
2017. (For interpretation of the references to color in this figure legend, the reader is referred to the web version of this article.)

over which the progradation is considered, being the one in the present study dealing with sudden changes on a scale of years whilst these other studies relate to foredunes experiencing long-term beach progradation.

The foredune position can be seen as a function of the beach width or slope and sediment supply. De Vries et al. (2012) have already shown a correlation between beach slope and dune volume change for the Dutch coast. Our results suggest that the relation between beach width, slope and foredune position is not linear. Moreover, our results suggest that the foredune position can also be seen as a function of the initial profile elevation. For Ameland, which has similar tide level and wave forcing between two considered sites with different beach width, dunes tend to form on lower elevations on wider beaches than narrow ones, which is in line with our model results. A hypothesis is that the position is conditioned by hydrodynamic erosion and available space at the upper beach for dune growth. Wider beaches would dissipate more wave energy than narrow beaches, which would increase the limit for dune extension. This is in line with our model results, which shows an inverse relationship between foredune position and slope. A wide beach offers an increased surf zone for energy dissipation and, consequently, limits wave run-up in the beach face. Therefore, steeper slope translates into hydrodynamic action reaching higher elevations on the profile, thus shifting foredune position to higher elevations than in mild slopes.

Our results further suggest that for narrow beaches, supply limiting factors such as groundwater can be more important than beach width in terms of dune volume, as can be seen on the dune volume 
increase results. Delgado-Fernandez and Davidson-Arnott (2011) already discussed that limiting factors such as surface moisture and ice/snow are capable of preventing transport events even though potential wind speed and enough fetch was present. De Vries et al. (2012) also suggest that transport-limiting processes govern dune volume development, whereas Keijsers et al. (2014) suggest that, for beaches smaller than $200 \mathrm{~m}$, temporal variability in dune volume is correlated with storm proxies. Our results suggest that, for narrow beaches, hydrodynamic sedimentation outside the intertidal area (i.e. upper beach) is negative for both unlimited and limited supply conditions (Fig. 12b). Having an erosive trend in the upper beach means that the total aeolian input that deposits at the foredune is reduced by hydrodynamic action. For wider beaches as sand flats, the hydrodynamic input outside the intertidal area is positive, which means that the influence of erosion is reduced, leading to a more prominent influence of local supply conditions (e.g. groundwater level) for the overall dune volume. The erosive control on narrow beaches also explains the high variability found in our results for narrow beaches, since erosion closer to the dunefoot is more frequent and dune morphology would not be controlled in majority by supply, but also by erosion, which is in accordance to Keijsers et al. (2014).

To model the influence of beach width on dune development, it is crucial that all other parameters are unaltered throughout different scenarios, so dune changes can be analysed solely on regards of beach width change. However, in reality, it is extremely difficult (if not impossible) to find different sites where all conditions that influence dune development are the same except for beach width. Thus, in this paper direct comparison with real data is maintained solely at the qualitative scale. Even so, it is important to note that dune differences between different sites in the presented real cases are not only influenced by the variations on beach width, but also by different wind strength and direction, grain size variability, local groundwater variations and shell pavement, which could not be accounted. Also, it is important to mention that, for narrow beaches, beach width can be

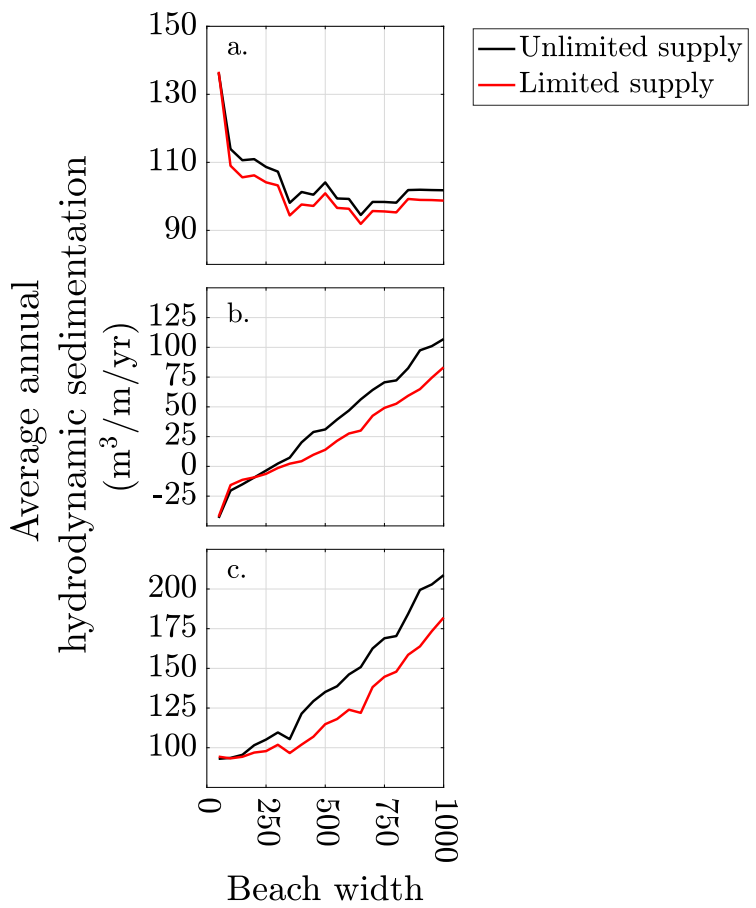

$(\mathrm{m})$

Fig. 12. Annual average hydrodynamic sedimentation for static scenarios, showing the net sedimentation in the intertidal area (a.), upper beach (b.) and whole profile (c.). Positive values referring to hydrodynamic accretion and negative values to hydrodynamic erosion. a limitation not only for space, but also for potential aeolian transport if beach width size is smaller than a potential critical fetch length. Critical fetch relates to a saturation of transport after some distance on which an increase in the fetch does not translate into more sand being transported (Bauer and Davidson-Arnott, 2002). If beach width is larger than potential critical fetch, small changes in beach width would have a limited effect in terms of aeolian transport, though it might influence dune position due to increased space and wave dissipation. On the other hand, if beach width is small, small changes in beach width do not only affect space and wave dissipation but also potential transport. Nevertheless, the model suggests that only beach width changes can lead to similar beach-dune variability, as found in the real cases, though its percentage of influence remain uncertain.

A relationship between hydrodynamic forces and the aeolian/biological forces is also seen by Durán Vinent and Moore (2014) on the scope of barrier island evolution. The authors argue that if dune recovering processes dominate, islands tend to become high in elevation and low regarding vulnerability to storms, whereas a perpetual long-term trend of low elevation and high vulnerability to storms might be present when erosion processes dominate. Considering this binary state, our study elaborates on the former, suggesting that the balance between hydrodynamic erosion and recovery capacity can also control dune states in smaller temporal scales. On narrow beaches, the hydrodynamic erosion and dune recovery potential control dune volume, whereas sediment supply and beach width would control the foredune position. Moreover, considering a changing beach width scenario, the increase in beach width does not necessarily translate into volume changes at the dunes, since the amount of sand transported towards the dunes can be significantly limited by other factors than yield by the potential increase of beach width. In contrast, dynamic tests showed that for narrow beaches, periodic increase in beach width may increase dune volume in the long-term. For wider beaches, changes in beach width only affect the foredune position.

\section{Conclusion}

A cellular automata model was used to evaluate the effect of varying beach width on coastal dune development at yearly to decadal scales. Several simulations were done using idealised beach profiles, different sediment supply conditions and static/dynamic behaviour of the shoreline. Results show that there is a preferential cross-shore position where the foredune tend to grow which varies with beach width. Moreover, foredunes at narrow beaches tend to develop at higher elevations than at wider beaches, whilst supply limitation factors such as groundwater depth can dominate over the effect of beach width increase on dune volume for narrow beaches. Furthermore, beach width controls the aeolian deposition zone where incipient dunes can emerge, thus controlling the space available for dune development. Therefore, beach width controls the space available for dune formation, and thus the position of the most seaward dune, but the effect of beach width on dune volume can be overruled by other supply limiting conditions such as groundwater depth. Thus, for time-varying beach widths, initial beach widths and retreat time would define what would be the most important controls for foredune dynamics.

\section{Acknowledgments}

This research forms a component of the CoCoChannel project (Co-designing Coasts using natural Channel-shoal dynamics), which is funded by Netherlands Organization for Scientific Research, Earth Sciences division (NWO-ALW), and co-funded by Hoogheemraadschap Hollands Noorderkwartier. We further wish to 
acknowledge Rijkswaterstaat for making their valuable bathymetric and topographic data sets freely available, as well as the water level data. Furthermore, we would like to thank two anonymous reviewers for their constructive comments.

\section{References}

Aagaard, T., Nielsen, J., Jensen, S.G., Friderichsen, J., 2004. Longshore sediment transport and coastal erosion at Skallingen, Denmark. Geogr. Tidsskr.-Dan. J. Geogr. 104 (1), 5-14.

Anthony, E.J., 2013. Storms, shoreface morphodynamics, sand supply, and the accretion and erosion of coastal dune barriers in the southern North Sea. Geomorphology 199, 8-21.

Barchyn, T.E., Hugenholtz, C.H., 2012. Predicting vegetation-stabilized dune field morphology. Geophys. Res. Lett. 39 (17). n/a-n/a.

Bauer, B.O., Davidson-Arnott, R.G.D., 2002. A general framework for modeling sediment supply to coastal dunes including wind angle, beach geometry, and fetch effects. Geomorphology 49 (1), 89-108.

Bauer, B.O., Davidson-Arnott, R.G.D., Hesp, P. a., Namikas, S.L., Ollerhead, J., Walker, I.J., 2009. Aeolian sediment transport on a beach: surface moisture, wind fetch, and mean transport. Geomorphology 105 (1-2), 106-116.

Bochev-van der Burgh, L.M., Wijnberg, K.M., Hulscher, S.J.M.H., 2009. Dune morphology along a nourished coastline. J. Coast. Res. (56), 292-296.

Burroughs, S.M., Tebbens, S.F., 2008. Dune retreat and shoreline change on the outer banks of North Carolina. J. Coast. Res. 24 (2B), 104-112.

Clarke, D., Eliot, I., 1983. Mean sea-level and beach-width variation at Scarborough, Western Australia. Mar. Geol. 51 (3), 251-267.

Cohn, N., Ruggiero, P., de Vries, S., García-Medina, G., 2017. Beach growth driven by intertidal sandbar welding. Proceedings of Coastal Dynamics 2017.

Davidson-Arnott, R.G., MacQuarrie, K., Aagaard, T., 2005. The effect of wind gusts, moisture content and fetch length on sand transport on a beach. Geomorphology 68 (1-2), 115-129.

Davidson-Arnott, R.G.D., Heyningen, A.G.V., 2003. Migration and sedimentology of longshore sandwaves, Long Point, Lake Erie, Canada. Sedimentology 50 (6), 1123-1137.

Davidson-Arnott, R.G.D., Law, M.N., 1996. Measurement and prediction of long-term sediment supply to coastal foredunes. J. Coast. Res. 12 (3), 654-663.

De Vries, S., Southgate, H.N., Kanning, W., Ranasinghe, R., 2012. Dune behavior and aeolian transport on decadal timescales. Coast. Eng. 67, 41-53.

Delgado-Fernandez, I., 2010. A review of the application of the fetch effect to modelling sand supply to coastal foredunes. Aeolian Res. 2 (2-3), 61-70.

Delgado-Fernandez, I., Davidson-Arnott, R., 2011. Meso-scale aeolian sediment input to coastal dunes: the nature of aeolian transport events. Geomorphology 126 (1-2), 217-232.

Durán Vinent, O., Moore, L.J., 2014. Barrier island bistability induced by biophysical interactions. Nat. Clim. Chang. 5 (December), 158-162.

Eastwood, E., Nield, J., Baas, A., Kocurek, G., 2011. Modelling controls on aeolian dune-field pattern evolution. Sedimentology 58 (6), 1391-1406.

Fonstad, M.A., 2006. Cellular automata as analysis and synthesis engines at the geomorphology-ecology interface. Geomorphology 77 (3), 217-234. Linking Geomorphology and Ecology.

Fonstad, M., 2013. Cellular automata in geomorphology. In: Shroder, J.F. (Ed.), Treatise on geomorphology. Academic Press, San Diego, pp. 117-134.
Heathfield, D.K., Walker, I.J., 2015. Evolution of a foredune and backshore river complex on a high-energy, drift-aligned beach. Geomorphology 248, 440-451.

Hesp, P., 1983. Morphodynamics of incipient foredunes in New South Wales, Australia. Dev. Sedimentol. 38 (C), 325-342.

Hesp, P., 2002. Foredunes and blowouts: initiation, geomorphology and dynamics. Geomorphology 48 (1-3), 245-268.

Hesp, P., Walker, I., 2013. Coastal dunes. Treatise on Geomorphology. Elsevier., pp. 328-355.

Hoad, K., Robinson, S., Davies, R., 2011. Autosimoa: a framework for automated analysis of simulation output. J. Simul. 5 (1), 9-24.

Keijsers, J.G., de Groot, A.V., Riksen, M.J., 2015. Vegetation and sedimentation on coastal foredunes. Geomorphology 228, 723-734.

Keijsers, J.G.S., Groot, A.V.D., Riksen, M.J.P.M., 2016. Modeling the biogeomorphic evolution of coastal dunes in response to climate change. J. Geophys. Res. Earth Surf. 121 (6), 1161-1181.

Keijsers, J.G.S., Poortinga, A., Riksen, M.J.P.M., Maroulis, J., 2014. Spatio-temporal variability in accretion and erosion of coastal foredunes in the Netherlands: regional climate and local topography.. PloS one 9 (3), e91115.

Law, A.M., 2014. Simulation Modeling and Analysis. McGraw-Hill Education - Europe.

Nield, J.M., Baas, A.C.W., 2008. Investigating parabolic and nebkha dune formatrion using a cellular automaton modelling approach. Earth Surf. Process. Landf. 33 (5), 724-740.

Quartel, S., Kroon, a., Ruessink, B., 2008. Seasonal accretion and erosion patterns of a microtidal sandy beach. Mar. Geol. 250 (1-2), 19-33.

Ridderinkhof, W., Hoekstra, P., van der Vegt, M., de Swart, H., 2016. Cyclic behavior of sandy shoals on the ebb-tidal deltas of the Wadden Sea. Cont. Shelf Res. 115 14-26.

Ruessink, B.G., Jeuken, M.C.J.L., 2002. Dunefoot dynamics along the Dutch coast. Earth Surf. Process. Landf. 27 (10), 1043-1056.

Sherman, D.J., Bauer, B.O., 1993. Dynamics of beach-dune systems. Prog. Phys. Geogr. 17 (4), 413-447.

Silva, F.G., Wijnberg, K.M., de Groot, A.V., Hulscher, S.J.M.H., 2018. The influence of groundwater depth on coastal dune development at sand flats close to inlets. Ocean Dyn. 68 (7), 885-897.

Stewart, C.J., Davidson-Arnott, R.G., 1988. Morphology, formation and migration of longshore sandwaves; Long Point, Lake Erie, Canada. Mar. Geol. 81 (1), 63-77.

Stive, M.J., Aarninkhof, S.G., Hamm, L., Hanson, H., Larson, M., Wijnberg, K.M., Nicholls, R.J., Capobianco, M., 2002. Variability of shore and shoreline evolution. Coast. Eng. 47 (2), 211-235.

Stockdon, H.F., Holman, R. a., Howd, P. a., Sallenger, A.H., 2006. Empirical parameterization of setup, swash, and runup. Coast. Eng. 53 (7), 573-588.

van der Burgh, L.B., Wijnberg, K., Hulscher, S., 2011. Decadal-scale morphologic variability of managed coastal dunes. Coast. Eng. 58 (9), 927-936.

van Puijenbroek, M.E., Limpens, J., de Groot, A.V., Riksen, M.J., Gleichman, M., Slim, P.A., van Dobben, H.F., Berendse, F., 2017. Embryo dune development drivers: beach morphology, growing season precipitation, and storms. Earth Surf. Process. Landf. 4144 ,

Wijnberg, K.M., 2002. Environmental controls on decadal morphologic behaviour of the holland coast. Mar. Geol. 27,

Zhang, W., Schneider, R., Kolb, J., Teichmann, T., Dudzinska-Nowak, J., Harff, J., Hanebuth, T.J., 2015. Land-sea interaction and morphogenesis of coastal foredunes - a modeling case study from the Southern Baltic Sea coast. Coast. Eng. 99, $148-166$. 